\title{
A krónikus szívelégtelenség és a 2-es típusú cukorbetegség
}

\author{
Tihanyi László, Veress Gábor
}

Állami Szívkórház, Balatonfüred

Levelezési cím: 8230 Balatonfüred,Gyógy tér 2., e-mail: tihanyi@mail.bfkor.hu

Jelen összefoglaló közlemény a krónikus szívelégtelenség és a 2-es típusú cukorbetegség együttes előfordulását tárgyalja. Irodalmi adatok alapján bemutatjuk elsősorban a 2-es típusú diabetes mellitus aspektusából napjaink terápiás lehetőségeit.

A diabéteszes cardiomyopathia önálló klinikai entitás. A kialakulásában nem játszik szerepet sem a hipertónia sem pedig az epikardiális koronária artériák szűkületei, elzáródásai. Olyan myocardium-diszfunkcióról van szó amelynek okai a microangiopathia okozta myocyta hypoxia, a glükotoxicitás és a lipotoxicitás.

A szulfanilurea és inzulin alkalmazása biztonságosság tekintetében nem optimális keringési elégtelenségben szenvedő betegek esetén. Az új típusú antidiabetikumok kardiovaszkuláris szempontból biztonságosak, a GLP1-analógok és az SGLT2-gátlók szignifikánsan csökkentették a szívelégtelenség miatti hospitalizációt és összmortalitást.

Kulcsszavak: krónikus szívelégtelenség, 2-es típusú diabetes mellitus, diabéteszes cardiomyopathia

\section{Chronic heart failure and type 2 diabetes}

This summary discusses the coincidence of chronic heart failure and type 2 diabetes. Based on the literature, we present the therapeutic possibilities from the aspect of type 2 diabetes that is available today.

Diabetic cardiomyopathy is a distinct clinical entity. Neither the hypertonia nor the narrowing of the epicardial coronary arteries are involved in its development. Myocardial dysfunction is due to microangiopathic myocyte hypoxia, glucotoxicity and lipotoxicity.

The use of sulfonylurea and insulin is not optimal with regard to safety in patients with circulatory insufficiency. The new type of antidiabetics are cardiovascularly safe, GLP-1 analogues and SGLT-2 inhibitors significantly reduced hospitalization and total mortality connected to heart failure.

Keywords: type 2 diabetes mellitus, heart failure, diabetic cardiomyopathy

A krónikus szívelégtelenség ma kb. 38 millió embert érint a világon, a betegek száma folyamatosan növekszik. 1990-ben még 23 millió szívelégtelen beteget regisztráltak, és 2030-ig a betegek számának 46\%-os növekedése várható $(1,2)$.

A betegség hosszú távú prognózisa továbbra sem jó, bár a különböző szívelégtelenség-típusok közt jelentős eltérések mutatkoznak mind a kezelés, mind a prognózis vonatkozásában. Problémát jelent, úgy az élet minősége, valamint a kórházi költségek vonatkozásában az is, hogy az ezzel a diagnózissal kezelt betegek 20\%-a harminc napon belül ismételt hospitalizációra szorul, fél éven belül pedig 50\%-uk kerül vissza állapotromlás miatt a kórházakba $(3,4)$. A 2-TDM szívelégtelenség nélkül önmagában a kardiovaszkuláris mortalitást 2,45-szörösére növeli. A szívelégtelenség prevalenciája 2-TDM-ben 10-23\% (5). A 2-es típusú diabetes mellitus szívelégtelenséggel szövődött formáinak a mortalitása nagyon magas, 10-12-szerese azon cukorbetegekhez viszonyítva, akikben keringési elégte- 
lenség nem alakult ki 60 év feletti életkorban (6). A 60 év feletti betegek 27,7\%-ának a szívelégtelensége nem diagnosztizált (7). A prediabétesz és a nem diagnosztizált 2-TDM gyakorisága a PARADIGM HF-Trial (HFrEF) betegein 25, illetve 13\%-nak adódott (8).

A Framingham Study igazolta elsőként, hogy a diabetes mellitus a szívelégtelenség független rizikófaktora. A szívelégtelenség sokokú, soktünetű klinikai entitás. 2016-ban a European Society of Cardiology (ESC) a szívelégtelenségben szenvedő betegeket három csoportra osztotta, az ejekciós frakció értékek alapján, annak a tudatában, miszerint az EF ugyan jól reprodukálható, de nem ideális markere a balkamra-funkciónak. A pontos osztályozáshoz szükség van a klinikum mellett a HFrEF-csoportot kivéve, az NT-ProBNP-értékek ismeretére is. Ezen felosztás alapján az alábbi három kategóriát különböztették meg:

1. $\mathrm{HFrEF}<40 \%$ (HF with reduced ejectios fraction) + szívelégtelenségre jellemző tünetek,

2. $\mathrm{HFmrEF}=40-49 \%$ (HF with mid-range ejectios fraction)+szívelégtelenségre jellemző tünetek+emelkedett NT-proBNP-szint,

3. $\mathrm{HFpEF}>50 \%$ ( $\mathrm{HF}$ with preserved $\mathrm{EF}$ )+szívelégtelenségre jellemző tünetek+emelkedett NT-proBNPszint.

A HFmrEF- és a HFpEF-csoport tagjaira jellemző a strukturális szívbetegség mellett a dominálóan diasztolés funkciózavar megléte is (9).

$\mathrm{Az}$ elmúlt harminc évben számos vizsgálatot végeztek ACE-I (angiotenzin konvertáz enzim blokkolók), ARB (angiotenzinreceptor-blokkolók), ß-receptor-blokkolók, valamint aldoszteron-antagonisták, az ivabradin és legutóbb a sacubitril/valsartan kombinációval, de a betegek $80-90 \%$-a a HFrEF-csoportba tartozott. Azon kevés számú vizsgálat, ami az imént felsorolt gyógyszerekkel történt HFpEF-es betegek körében kiábrándító eredményeket mutatott. A HFmrEF-csoport tagjai többnyire a HFrEF-esetekben alkalmazott terápiában részesültek, mivel korábban a HFrEF-csoportba tartoztak és éppen az eredményes kezelés hatására kerültek egy „osztállyal feljebb”. Ebben a szürke zónás csoportban az tudható, hogy a béta-blokkoló gyógyszerek, ha a beteg pitvarfibrillációban is szenved, nem csökkentik a mortalitást, de sinusritmus mellett igen (10). A CHARM-vizsgálat utólagos elemzése azt mutatta, hogy ezekben a betegekben a candesartan hatékonyan csökkentette a CV-halálozást és a szívelégtelenség miatti hospitalizációt.

A diabéteszes betegeket egyszerre sújtja az akcelerált koronáriabetegség, a diabéteszes cardiomyopathia, és a diabéteszes neuropathia. A diabéteszes cardiomyopathia ma már nem vitatottan önálló klinikai entitás, amelynek hátterében az oxidatív stressz, a lipotoxicitás, a glikált végtermékek felszaporodása állhat (11, 12). 1954-ben Lundbaek volt az első, aki leírt egy speciális diabétesz okozta szívizombetegséget, ami nem a hipertónia és nem is az epikardiális koronáriák kó- ros elváltozásainak következménye volt (13). 20 évvel később Rubler és munkatársai 4 páciensröl számoltak be posztmortem, akiknél a T-2DM okozta glomerulosclerosis mellett súlyos szívelégtelenséget találtak ép epikardiális koronáriák mellett (14). A diabétesz cardiomyopathia kialakulásának a patofiziológiai aspektusai meglehetősen bonyolultak és ma sem teljesen tisztázottak. Két tényezőt azonban célszerủ kiemelni:

1. a glükotoxicitás talaján kialakuló microangiopathia (a mikrovaszkulatúra progresszív pusztulása),

2. a lipotoxicitás.

A glikált proteinek felszaporodása (az advanced glycosilation end products - AGES) a szívizomsejtekben a citoplazmatikus enzimrendszerek károsodását okozhatja. A glükotoxicitás az arteriolák szintjén azok diszregulációját okozza, a kollagén bioszintézis fokozott stimulációja, valamint a kialakult endothel-diszfunkció (eNOS $\downarrow$ ) mellett. Normális körülmények között a szívizom által felhasznált energia (ATP) 95-96\%-a a mitokondriumban a terminális oxidáció során képződik. A fennmaradó néhány százalék a szubsztrát szintű foszforiláció terméke, amely a glikolízis során citoplazmában képződött ATP-t jelenti. A miocitákban is az ATP-termelés limitáló tényezője az oxigén, pontosabban a mitokondriumok környezetében mérhető oxigén parciális nyomása. Ennek elégtelen volta miatt a terminális oxidációs folyamat zavart szenved, a relatív oxigénhiány miatt a szívizomsejt belseje redukálttá válik, megnő a NADH/ $N A D$ hányados. Ez a magas hányados gátolja a piruvát-dehidrogenáz-kináz enzimet, amely következtében a glikolízis megáll, azaz a szívizomzat még azt a 4-5\% citoplazmatikus béta-oxidációból eredő ATP-t is elveszti (15). A légzési lánc további destrukcióját eredményezi a lipotoxicitás. Az inzulinrezisztencia következtében a szabad zsírsavak mennyisége megnövekszik a szívizomsejtekben, fokozódik a miociták triglicerid-akkumulációja. A kialakult miocita steatosis proton-magnetic resonance spektroszkópiával jól vizsgálható (16).

Összegzésképpen elmondható, hogy normál körülmények között a miociták inkább zsírsavakat égetnek, mint glükózt, mert előbbieknek nagyobb az energiatartalma, de ha az oxigén limitálóvá válik a nagyobb arányú glükózlebontás több olyan ATP-t eredményez, amelynek keletkezéséhez kevesebb oxigénre van szükség. Azonban ez a lehetőség, mint láttuk az inzulinrezisztencia és a lipotoxicitás miatt bezáródik, pedig a citoplazmában keletkezett ATP lokális hasznosíthatósága a membrán ATP-ázok számára valószínüleg jobb, mint a mitokondriumokban keletkezetteké $(17,18)$. Ezek az energetikai folyamatok a felelősek a miociták diszfunkciójáért és progresszív pusztulásáért, amely szövettanilag a szívizom-fibrosis képében jelenik meg (diabéteszes cardiomyopathia). A veséknél ugyanez a folyamat interkapilláris glomerulosclerosis kialakulásához vezet.

A diabétesz okozta cardiomyopathia az esetek többségében megtartott, vagy csak kismértékben csökkent szisztolés balkamra-funkcióval (HFpRF) jár. A kialakuló 
1. TÁBLÁZAT. A diasztolés diszfunkció stádiumainak meghatározásához az ASE/EACVI 2016. útmutató alapján

\begin{tabular}{|c|c|c|c|c|}
\hline & Normál & Grade I. & Grade II. & Grade III. \\
\hline LV-relaxáció & $\mathrm{N}$ & Károsodott & Károsodott & Károsodott \\
\hline LAP & $\mathrm{N}$ & Alacsony vagy $\mathrm{N}$ & Emelkedett & Emelkedett \\
\hline Mitral E/A Ratio & $\geq 0,8$ & $\leq 0,8$ & $>0,8$ to $<2$ & $>2$ \\
\hline E/e' Ratio & $<10$ & $<10$ & $10-14$ & $>14$ \\
\hline Peak TR velocity (m/sec) & $<2,8$ & $<2,8$ & $>2,8$ & $>2,8$ \\
\hline LA volume index & $\mathrm{N}$ & $\mathrm{N}$ vagy megnövekedett & Megnövekedett & Megnövekedett \\
\hline
\end{tabular}

myocardium-fibrosis talaján érthetővé válik, hogy erre a kórképre elsősorban a relaxáció, tehát a diasztolés funkció károsodása a jellemző. A diasztolés diszfunkció vizsgálata ma sem egyszerü, mivel a mitralis beáramlási görbe echovizsgálata nem ad elég pontos eredményt, az E/e', amely a bal kamrai végdiasztolés nyomás tükrözője lehet, némileg jobb, de a kezdeti lelkesedés mára már csökkenni látszik vele szemben (19). A balkamra-hipertrófia, a pitvarok mérete is szükséges a pontosabb diagnózishoz. A diasztolés diszfunkció echokardiográfiás diagnózisába nagy segítséget nyújthat az ASE/EACVI 2016-os guideline (1. táblázat). A guideline a diasztolés diszfunkció kialakulásának három strukturális és három funkcionális okát emeli ki. Strukturális eltérések:

1. hipertrófia,

2. fibrosis,

3. konstrikció.

Funkcionális eltérések:

1. iszkémia,

2. kalcium overload,

3. ATP-depléció.

Mint az imént láttuk, diabéteszes cardiomyopathiában jellemző a fibrosis és az ATP-depléció.

Szubklinikus szisztolés funkciócsökkenés az esetek túlnyomó többségében jelen van, de ezt elsősorban nem a kamrák cirkumferenciális, hanem inkább a longi-

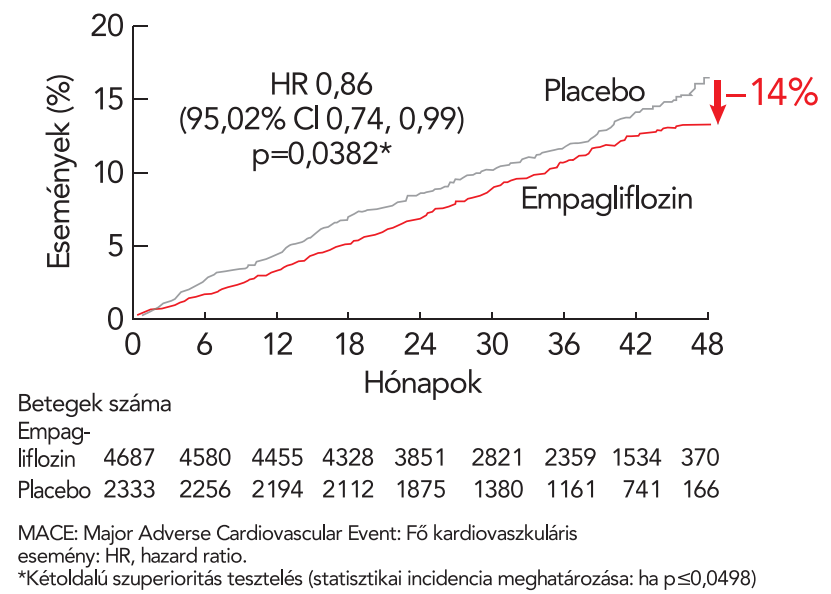

1. ÁBRA. Elsődleges végpont: a háromvégpontos MACE alakulása tudinális funkciójának a károsodása jellemzi. A MAPSE nem túl érzékeny marker, a speckle tracking jobb.

A diabetes mellitusban alkalmazott vércukorszint-csökkentő kezelések, az esetek egy részében rontották a szívelégtelenségben szenvedő betegek prognózisát, vagy jobb esetben ebből a szempontból neutrálisnak bizonyultak.

Ezért is keltett nagy feltűnést az SGLT2-gátló empagliflozin az EMPA-REG-vizsgálatban, amelyben a szívelégtelenség okozta hospitalizáció 35\% csökkenését sikerült kimutatni $(p<0,001)$, miközben más kardiális végpontok is pozitívan változtak (pl. a kardiovaszkuláris halálozás relatív rizikócsökkenése 38\%-nak adódott $(p<002)$, az összmortalitás is $32 \%$-os csökkenést mutatott $(p<0,001)(20)(1-4$. ábra).

2016-ban az ESC szívelégtelenség kezelésére kidolgozott irányelve minden diabéteszes szívelégtelen betegnél javasolja az empagliflozin adásának a mérlegelését. $A z$ ajánlás erőssége Ila/B. Később a canaglifozinnal végzett CANVAS-study hasonló eredményre vezetett szívelégtelenségben szenvedő betegek hospitalizációját illetően, az alsó végtagi amputációk számának a szignifikáns növekedése mellett! (21).

A CVDREAL-vizsgálat real life retrospektív obszervációs vizsgálat volt dapagliflozinnal, az ilyen típusú vizsgálatok előnyeivel és hátrányaival. A szívelégtelenségben szenvedő betegek hospitalizációja itt is csökkent,

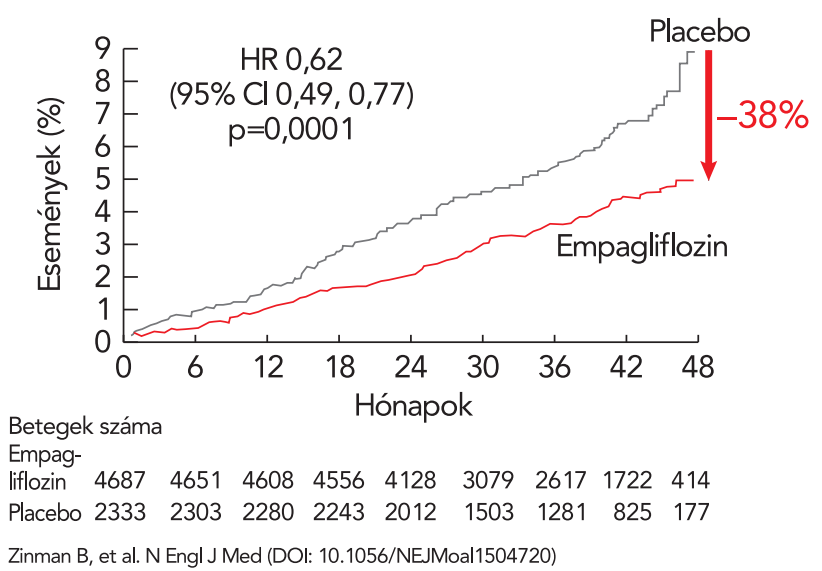

2. ÁBRA. A kardiovaszkuláris halálozás relatív rizikó csökkenése $38 \%$-nak adódott $(p<002)$ 


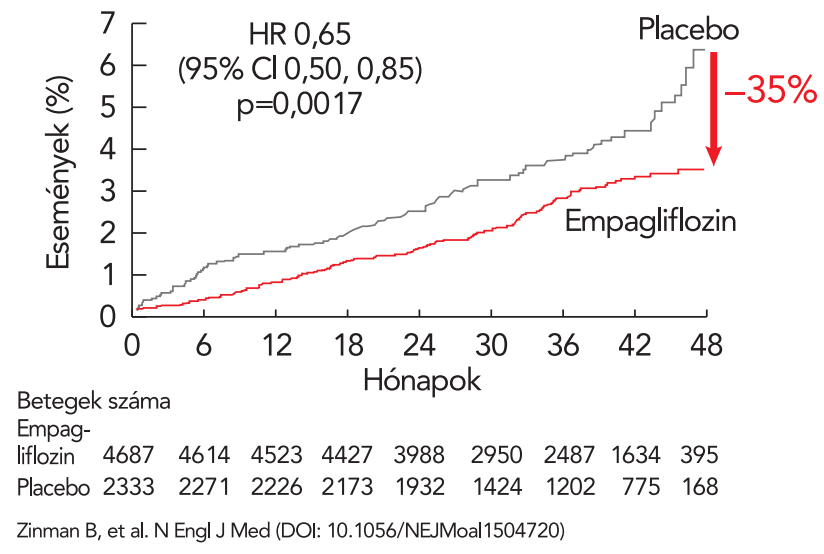

3. ÁBRA. A szívelégtelenség okozta hospitalizáció $35 \%$ csökkenését sikerült kimutatni $(p<0,001)$

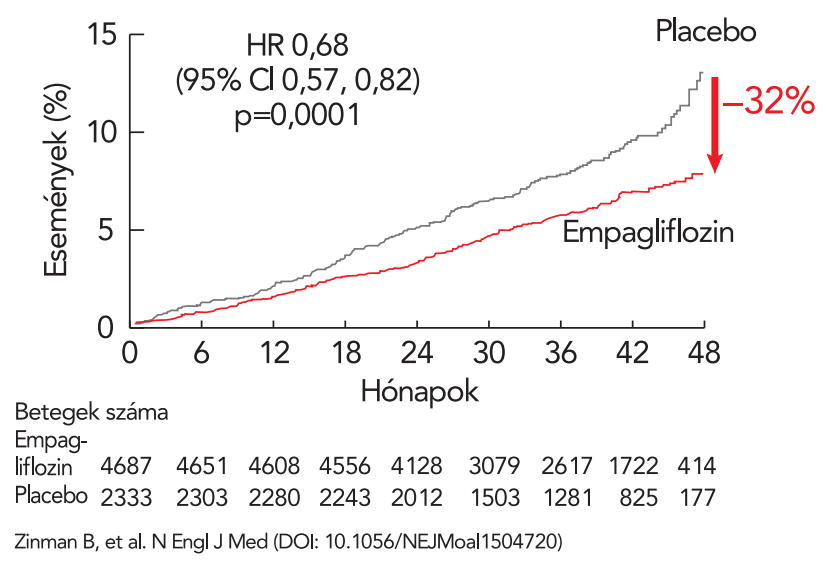

4. ÁBRA. Az összmortalitás is $32 \%$-os csökkenést mutatott $(p<0,001)(20)$ de az országok közti szórás mértéke elfogadhatatlanul nagynak bizonyult (Norvégia 38\%, Dánia 23\%, Németország 86\%!) (22).

Az EMPA-REG-vizsgálat alcsoport-elemzései alapján arra a következtetésre jutottak, hogy az empagliflozin jótékony hatásai nincsenek közvetlen összefüggésben sem a vércukorcsökkentő, sem a vérnyomáscsökkentő, sem pedig a vérzsírszint-csökkentő hatásokkal (23).

A pontos mechanizmus tisztázása érdekében indult el az EMPEROR-program, amelyben már célzottan keresik a választ arra, hogy a szívelégtelenség különböző típusaiban milyen hatásmechanizmusok magyarázzák az eddig észlelt klinikai tapasztalatokat (24).

\section{A krónikus szívelégtelenségben szenvedő cukorbetegek kezelése}

Tekintsük át, hogy krónikus szívelégtelenségben szenvedő cukorbetegek kezelését illetően milyen lehetőségeink vannak napjainkban.

A 2-es típusú diabéteszben elsőként ajánlott gyógyszer a metformin. A 2016-os ESC-ajánlás úgy foglal állást, hogy a gyógyszer valószínúleg növeli a túlélést (24).

Ugyanez a guideline a szulfonilureák vonatkozásában óvatosságra int. Talán a gliclazid tűnik a csoporton belül a legjobbnak, de a szívelégtelenség progressziójának veszélyével mindenképpen számolnunk kell (26). A glitazonok alkalmazása szívelégtelenségben szenvedő betegekben nem ajánlott! (27, 28, 29). A DPP4-gátlók közül a saxagliptin szignifikánsan emelte a szívelégtelenség miatti hospitalizációt (SAVOR-TIMI 53 study). $A z$ alogliptin nem szignifikáns mértékben ugyan, de szintén növelte a szívelegtelenség miatti hospitalizációt (EXAMINE-Study).

A sitagliptin volt eddig az egyetlen olyan DPP4-gátló gyógyszer, ami nem befolyásolta negatív értelemben a szívelégtelen betegek hospitalizációját, és a kardiovasz- kuláris halálozás összetett végpontját sem (TECOS). A GLP1-agonista liraglutid és semaglutid a szívelégtelenség miatti hospitalizációt nem csökkentette, de más végpontok vonatkozásában (összhalálozás, kardiovaszkuláris mortalitás, nem végzetes infarktus, nem végzetes stroke) szignifikáns csökkenést mutatott $(30$, 31). Az exenatiddal végzett vizsgálatok ELIXA, EXSCELL, viszont fenti végpontok vonatkozásában nem bizonyultak szuperiornak. A liraglutid és a semaglutid szuperioritása az exenatiddal szemben valószínűleg a molekulaszerkezetben rejlik, előbbi kettő GLP1-analógnak tekinthető, mivel szerkezetük 98\%-ban megegyezik a GLP1-hormonnal, míg az exenatidnál ez az arány sokkal kisebb (46\%). Ezért a liraglutidot és a semaglutidot GLP1-analógnak tartjuk, míg az exenatid GLP1-agonista. Ez a megkülönböztetés az imént említett vizsgálatok eredményeinek a tükrében klinikai szempontok alapján is indokoltnak látszik.

Nem tértünk még ki az inzulinkezelésre, ami nagyon sok esetben a betegség progresszív természete okán elkerülhetetlen. Az új típusú bázisinzulinok glargin, degludek kardiovaszkuláris biztonságossága mára már igazolódott, ORIGIN-, DEVOTE-vizsgálatok $(32,33)$. Az inzulin sokszor nem nélkülözhető hormonpótló kezelés, amely során törekedni kell a korszerü analóginzulin-rendszerek alkalmazására, mivel ezzel közelíthetjük meg a legjobban a természetes viszonyokat.

Ugyanakkor nem hagyható figyelmen kívül, hogy az inzulin erőteljes folyadék- és nátriumretenciót okoz, így ronthatja a szívelégtelenségben szenvedő cukorbetegek várható életkilátásait. Úgy tűnik ez a jelenség is dózisfüggő, ami még jobban aláhúzza a megfelelő étrend és testmozgás fontosságát, hogy minél kisebb adagokkal sikerüljön a betegek szénhidrátháztartását egyensúlyban tartani.

Napjainkban már nem elégedhetünk meg csupán anynyival, hogy egy adott antidiabetikum kardiovaszkuláris szempontból biztonságosnak bizonyul, bár kétségte- 
len, hogy a 2008 óta kötelezően elvárt kardiovaszkuláris biztonságossági követelményeknek ma már minden új antidiabetikus készítménynek meg kell felelnie. Előnyben kell részesítenünk a terápia megválasztásakor azokat a gyógyszereket, amelyeknél a kardiovaszkuláris előny bizonyított.

A korszerű antidiabetikus terápiától azt várjuk el, hogy a glikémiás hatékonyság mellett kardiovaszkulárisan előnyös legyen, csökkentse a testsúlyt, ne növelje a hypoglykaemiás kockázatot, mellékhatásai enyhék és könnyen kezelhetőek legyenek. Fontos szempont a kezelés ára, amit az imént említett szempontok figyelembe vételével célszerü kialakítani.

\section{Irodalom}

1. Braunwald $\mathrm{E}$. The war against heart failure the Lancet lecture. Lancet 2015; 385(9970): 812-24. doi: 10.1016/S0140-6736(14)61889-4 2. McMurray JJ, et al. Clinical epidemiology of heart failure public and private health burden Eur Heart J 1998; (Suppl P): 9-16.

3. Ross JS, et al. Recent national trend in readmission rates after heart failure hospitalisation Circ Heart Fail 2010; 3(19): 97-103. doi: 10.1161/CIRCHEARTFAILURE.109.885210

4. Connor CM. High Heart Failure Readmission Rates: Is It the Health System's Fault? JACC Heart Fail 2017; 5(5): 393. doi: 10.1016/j.jchf.2017.03.011

5. Cavender MA, Steg PG, et al. Impact of diabetes mellitus on hospitalization for heart failure, cardiovascular events, and death: outcomes at 4 years from the Reduction of Atherothrombosis for Continued Health (REACH) Registry. Circulartion 2015; 132: 923-931. doi: 10.1161/CIRCULATIONAHA.114.014796

6. Bertoni AG, Hundley WG, et al. Heart failure prevalence, incidence, and mortality in the elderly with diabetes. Diabetes Care 2004; 27: 699-703. doi: 10.2337/diacare.27.3.699

7. Boonman-de Winter LJ, Rutten FH, et al. High prevalence of previously unknown heart failure and left ventricular dysfunction in patients with típe 2 diabetes. Diabetologia 2012; 55: 2154-2162. doi: 10.1007/s00125-012-2579-0

8. Kristensen SL, Preiss D, et al. PARADIGM HF. Risk related to pre-diabetes mellitus and diabetes mellitus in heart failure with reduced ejection fraction: insights from Prospective Comparison of ARNI With ACEI to Determine Impact on Global Mortality and Morbidity in Heart Failure Trial. Circ Heart Fail 2016; 9: e002560. doi: 10.1161/ CIRCHEARTFAILURE.115.002560

9. Ponikowski P, Voors AA. 2016 ESC Guidelines. Eur Heart J 2016 37: 2129-2200.

10. Lund LH, Oldgren J. Registry based pragmatic trials in heart failure: current experience and future directions. Curr Heart Fail Rep 2017; 14: 59-70. doi: 10.1007/s11897-017-0325-0

11. Ernande L. Derumeaux G.Diabetic cardiomypoathy: myth or reality? Arch Cardiovasc Dis 2012; 105: 218-225. doi: 10.1016/j. acvd.2011.11.007

12. Lundbaek K. Diabetic angiopathy: a specific vascular disease Lancet 1954; 266: 377-379. doi: 10.1016/S0140-6736(54)90924-1

13. Rubler S, Dlugash J, et al. New type of cardiomyopathy associated with diabetic glomerulosclerosis. Am J Cardiol 1972; 30: 595-602. doi: 10.1016/0002-9149(72)90595-4
14. Rijzewijk LJ, van der Meer RW, et al. Myocardial steatosis is an independent predictor of diastolic dysfunction in type 2 diabetes mellitus. J Am Coll Cardiol 2008; 52: 1793-1799. doi: 10.1016/j. jacc.2008.07.062

15. Lopaschuk GD, Belke DD, et al. Regulation of fatty acid oxidation in the mammalian heart in health and disease. Biochim Biophys Acta 1994; 1213(3): 263-276. doi: 10.1016/0005-2760(94)00082-4

16. Zhang M, Kho AL, et al. Glycated proteins stimulate reactive oxygen species production in cardiac myocytes: involvement of Nox2 (gp91phox)-containing NADPH oxidase. Circulation 2006; 113: 1235-1243.

17. Stanley WC, Lopaschuk GD, et al. Regulation of myocardial carbohydrate metabolism under normal and ischaemic conditions. Potential for pharmacological interventions. Cardiovasc Res 1997; 33(2): 243-257. doi: 10.1016/S0008-6363(96)00245-3

18. Jafri MS, Dudycha SJ, et al. Cardiac energy metabolism: models of cellular respiration. Annu Rev Biomed Eng 2001; 3: 57-81.

19. Oleg F. Sharifov, Himanshu Gupta. What is the evidence that the tissue doppler index E/e' reflects left venticular filling pressure changes after exercise or pharmacological intervention for evaluating diastolic funtion? A systematic review. J Am Heart Assoc 2017; 6: e004766. DOI: 10.1161/JAHA. 116. 004766.

20. Zinman B, Wanner, et al. EMPA-REG OUTCOME Investigators. Empagliflozin, cardiovasc.outcomes,amd mortality in type 2 diabetes. N Engl J Med 2015; 373: 2117-2128. doi: 10.1056/NEJMoa1504720

21. Neal B, Perkovic V, et al. CANVAS Program Collaborativ Group. Canagiflozin and cardiovascular and renal events in type 2 diabetes. N Eng J Med 2017; 377: 644-6024. doi: 10.1056/NEJMoa1611925 22. Kosiborod M, Cavender MA, et al. LOwer risk of heart failure and death in patients initiated on SGLT-2 inhibitors versus other glucose lowering drugs The CVD-REAL Study. Circulation 2017 May 18.

23. Savarese GD, Amore C, et al. Effect of dipeptidyl peptidase! and Sodium -Glucose Linked co Transporter-2 inhibitors on cardiovasc events in patients with type 2 diabetes mellitus. Int J Cardiol 2016; 220: 595-601.

24. Buttler J, Hamo CE, et al. EMPEROR Trails Program. Eur J Heart Fail 2017; 19: 1390-1400.

25. Ponikowski P, Voors AA, et al. 2016 ESC Gudelines for ther. diagnosis and treatment of acute and chronic heart failure. Eur J Heart Fail 2016; 18: 891-957. doi: 10.1002/ejhf.592

26. Pantalone KM, Kattan MW, et al. The risk of overall mortality in patinets with type 2 diabetes receiving gliclazid, gliburide, or glimepiride monotherapy. Diabetes CRE 2010; 33(6): 1224-1229. doi: 10.2337/dc10-0017

27. Dargie, H. GSK 211, Pro-ACTIVE) H. Dargie H, P Hildebrand G ACC Orlando march. 2015

28. Wilcox R, et al. Am Heart J 2008. PRO-active study

29. Glibert RE, Krum H. Heart failure in diabetes: Effects of anti-hyperglycemic drug therapy. Lancet 2015; 385: 2107-17. doi: 10.14341/ DM2003451-57

30. LEADER, Marso SP, Poultier NR, et al. Am Heart J 2013; 166 823-830. doi: 10.1016/j.ahj.2013.07.012

31. SUSTAIN 6. SP Marso, SC. Bain, et al. New England Journal of Medicine 2016; 375(19): 1834-1844. doi: 10.1056/NEJMoa1607141 32. The ORIGIN Trial Investigators: Basal insulin and cardiovascular and other outcomes in dysglycemia. N Eng J Med 2012; 367: 319328. doi: 10.1056/NEJMoa1203858

33. Marso SP, Mc Guire DK, et al. Efficacy and safety of degludec vs. glargine in type 2 diabetes. N England J Med 2017; 377(8): 723-732. doi: 10.1056/NEJMoa1615692

A közlemény megjelenését a Boehringer Ingelheim támogatta.

A közlemény tartalma a cikkíró saját szakmai álláspontját tükrözi, és nem tekinthető a Boehringer Ingelheim részéről közzétett szakmai vagy egyéb tájékoztatásnak vagy állásfoglalásnak.

A cikkben megemlített termékek használatakor az érvényes alkalmazási előírás az irányadó.

PC-HU-100306, Lezárás dátuma: 2018. 11. 09 